Long, Ryan. "Ethics, Rights, and White's Antitrust Skepticism." The Antitrust Bulletin 61, no. 2 (2016):

336-341. (open access, non-formatted version)

\title{
Ethics, Rights, and White's Antitrust Skepticism
}

\author{
Ryan Long*
}

Mark White has developed a provocative skepticism about antitrust law. I first argue against three claims that are essential to his argument: the state may legitimately constrain or punish only conduct that violates someone's rights, the market's purpose is coordinating and maximizing individual autonomy, and property rights should be completely insulated from democratic deliberation. I then sketch a case that persons might have a right to a competitive market. If so, antitrust law does deal with conduct that violates rights. The main thread running throughout the article is that what counts as a legitimate exercise of property rights is dynamic, sensitive to various external conditions, and is the proper object of democratic deliberation.

\section{I.INTRODUCTION}

Mark White has developed a provocative skepticism about antitrust law. ${ }^{1}$ I will focus on three parts of his argument:

1. The state may legitimately constrain or punish only conduct that violates someone's rights.

2. The market's purpose is coordinating and maximizing individual autonomy.

3. Property rights should be completely insulated from democratic deliberation.

I will defend antitrust law by providing counter-arguments to each of these claims. I will also argue that granting (1) and (2) does not entail White's skepticism.

\section{HARMS AND WRONGS}

\section{A. Legitimate constraint}

White assumes that the state may legitimately constrain only conduct that is wrongful. Merely harmful conduct should not be constrained. Wrongs are then defined in terms of rights violations. Thus the coercive power of the state should only constrain conduct that violates some person's rights. Compare this to Mill's harm principle, which may also constrain and punish conduct that is "prejudicial to the interests of others." 2 White's principle is narrower, since not all harms are rights violations.

\footnotetext{
* Assistant Professor of Philosophy, Philadelphia University.

${ }^{1}$ Mark D. White, On the Justification of Antitrust: A Matter of Rights and Wrongs, Antitrust Bull. (2016, this issue)

2 JOHN STUART MILL, ON LIBERTY (1869).
} 
Long, Ryan. "Ethics, Rights, and White's Antitrust Skepticism." The Antitrust Bulletin 61, no. 2 (2016):

336-341. (open access, non-formatted version)

White contrasts his principle with welfare utilitarianism and rejects the latter because individual rights trump welfarist concerns. White does not consider other options. Note that most legal systems constrain some conduct for rationales that are neither rights-based nor utilitarian. Prohibitions of public nudity here in Philadelphia are not based on rights or welfare rationales, but rather community standards. The American legal system does not affirm Mill's harm principle, much less White's narrower principle. There may be alternative justifications of antitrust that are not addressed in White's analysis.

My first worry about White's view is that one cannot resolutely hold the principle that only wrongs may be constrained. Acts that are not wrongs could collectively cause so much harm that life would become miserable or impossible. Mill's approach is better suited to handle this problem. Rather than accept the wider form of Mill's harm principle, White transitions from the claim that rights are trumps to the conclusion that legitimate constraint may only address conduct that violates rights. But even if you accept the view that rights are trumps, and take this as a reason to reject welfare utilitarianism, you are not committed to the view that everything reduces to rights. Rawls argued that the liberty principle (dealing with rights) always takes priority over welfare utilitarian reasoning, and that welfare maximizing policies must never trump the inviolability of the person. ${ }^{3}$ Yet Rawls does not end up with a view that restricts legitimate constraint to conduct that violates individual rights. Even if welfare utilitarianism fails to adequately account for individual rights, the conclusion that everything is a matter of rights does not immediately follow.

One may also object that wrongs cannot be defined in terms of rights. Certain sorts of conduct, such as callous disregard, might count as wrongs even when no rights are violated. Unwarranted cruelty to one's parents wrongs them but does not violate their rights.

\section{B. Mere harms}

White uses traffic congestion pricing to highlight the difference between wrongs and mere harms. "While such policy interventions may increase aggregate welfare, they address harms and behavior that were not wrongful and did not merit policy attention to correct." ${ }^{4}$ But congestion pricing can be understood solely as a market force rather than a sanction or constraint on behavior. As demand increases, the value of the resource increases. The increased demand can lower aggregate welfare and increase the cost of maintaining the resource. Congestion pricing has the consumer of the resource pay the bill. It is therefore not clear that we should understand this issue in terms of sanctions and constraints.

White then extends this analysis into a general skepticism about antitrust law, which targets behavior that he thinks is harmful but not wrongful. Firms harm consumers in many ways that do not involve trusts: raising prices unilaterally, changing products, or ceasing production of products. Neither these harms nor the

3 JOHN RAWLS, A THEORY OF JUSTICE 28 (Original Ed. 1971).

${ }^{4}$ White, supra note 1. 
Long, Ryan. "Ethics, Rights, and White's Antitrust Skepticism." The Antitrust Bulletin 61, no. 2 (2016):

336-341. (open access, non-formatted version)

harms caused by trusts violate rights, so why single out the harms of trusts for special civil and criminal enforcement? Why are these other harms less regulated? White thinks these are all mere harms, that all should be treated equally, and that we should accomplish this by rejecting antitrust regulation. In response, I will first argue that these harms are not all on par, then argue that trusts might in fact violate rights.

These non-trust harms cited by White create long term market opportunities for another firm to undercut the new price or to satisfy the demand for the discontinued product. The harms of monopolistic trusts do not allow (or at least hinder) these market responses, and therefore are a more serious form of harm, whether or not they violate rights. The market can repair the first sort of harms, and indeed the proponents of free markets see these short-term harms as part of the free market ideal. The market cannot in the same way repair harms of the second sort, which undermine the free market ideal. White treats these as on par, but the harms caused by trusts do not amount to any long-term good for any party other than the trust itself. They cause an entirely different sort of harm that is not part of a larger good and is antithetical to the purpose of the market.

White concludes that because the harms of trusts do not violate rights, antitrust constraints and sanctions are illegitimate. I have expressed skepticism about his principle that only wrongs may be constrained and argued that the harms caused by trusts are different from other sorts of harms caused by firms. Now let us examine what follows if White is correct that antitrust law is just only if trusts violate rights. Perhaps White does not identify the offended rights because he is looking at things in too fine detail: a right to a specific product, or a right to a product at a specific price, or a right to determine precisely how firms set prices. He is correct that consumers generally have no such rights. What about a right to a competitive market? White mentions this possibility but dismisses it. It may be the answer. If so, White's principle does not entail skepticism about antitrust law. To evaluate this option we must examine the relationship between property rights and White's claim that the purpose of the market is to coordinate and maximize autonomy.

\section{II.THE PURPOSE OF THE MARKET}

The question of whether antitrust violates rights has to do with the purpose of the market and the nature of property rights. White argues that the purpose of the market is to coordinate actions and maximize autonomy. "[T] he market is best regarded as a coordinating mechanism that ensures that individuals have the most freedom to pursue their interests consistent with all other doing the same. In this view the market is not a guarantor of prosperity or wealth but a process through which multiple individuals' choices may be coordinated." ${ }^{\prime \prime}$ This leaves us with two problems. First, a market may be constituted such that most agents' autonomy is frustrated. Second, the norm is to enter markets without making an autonomous choice. The circumstances of one's birth typically determine the market within

${ }^{5}$ White, supra note 1. 
Long, Ryan. "Ethics, Rights, and White's Antitrust Skepticism." The Antitrust Bulletin 61, no. 2 (2016):

336-341. (open access, non-formatted version)

which one exerts autonomy. Emigration does not solve this objection since it is not available to all, and the world may be constituted such that no available market furthers autonomy.

If maximizing autonomy is the purpose of the market, but we do not enter markets autonomously, perhaps we should recognize hypothetical conditions on the market. Is a given market such that one would freely enter into it? A rational agent who is convinced that capitalism is the best way to organize the market, but who lacks knowledge of his peculiar advantages and disadvantages, will only choose to enter a market that is competitive, or at least is the most competitive of the available options. A noncompetitive market is fundamentally at odds with this view of the function of markets and the value of autonomy. This means that only a competitive market satisfies the purpose of the market, and thus agents have a right to a competitive market. Indeed, White treats firms as persons, and we can run this argument from the firm's perspective. If a firm does not know whether it (or its competitors) are in a position to engage in monopolistic conduct, it would only be rational to enter a competitive market.

Also note that White's rejection of the welfare-maximization view of the market does not automatically mean the market has no other purpose than furthering autonomy. Again, Rawls rejects welfare maximization but does not end up with White's view. Rawls combines a rights-as-trumps view with thinking the market has the purpose of making all better off while maximizing the absolute condition of the worst-off. The basic structure of the state should be designed such that the market serves this purpose.

White also argues that a market cannot have another purpose because no persons or firms have an obligation to pursue that purpose. This issue requires more analysis. White's general idea is that the purpose of the market cannot be to maximize aggregate welfare since no person is obligated to act in a way that will contribute to that purpose. Yet it is not clear that the market having a particular purpose entails that anyone is obligated to have all their actions serve that purpose. Rawls argues that the market has the purpose just described, but no person has an obligation to pursue that purpose. The basic structure of society should ensure that the market serves this purpose while individuals may make economic decisions based on their self-interest. Without an additional argument we need not accept the claim that for the market to have a specific purpose other than maximizing autonomy, specific persons must be obligated to further that purpose.

\section{III.PROPERTY RIGHTS}

White also argues that property rights must be completely insulated from democratic deliberation. He sees antitrust law as a misuse of democratic political power that illegitimately constraints the exercise of property rights. This is unacceptable because rights should be trumps; deliberation among the population about how to maximize welfare (or any other concern) cannot violate property rights. Therefore the state has no authority to limit property rights, even when they are exercised in a way that hinders the competitiveness of the market. 
Long, Ryan. "Ethics, Rights, and White's Antitrust Skepticism." The Antitrust Bulletin 61, no. 2 (2016):

336-341. (open access, non-formatted version)

However, this insulation is impossible. There are questions about the precise nature of property rights that cannot be answered solely by a priori analysis or empirical investigation. The problem is not that property rights must be subject to democratic deliberation because they only come into being within a particular political structure. Grant for the sake of argument that Locke was correct. Property rights pre-date civil society and originate in the state of nature. ${ }^{6}$ Nonetheless, in a democracy, property rights must be subject to democratic deliberation.

White objects that democratic legislatures may not constrain non-wrongful exercises of property rights. "If that behavior is a legitimate exercise of rights that causes no wrongful harms to consumers or other firms, it is irrelevant whether that behavior is socially undesirable or disliked by the majority---it should be protected as a matter of right and justice." I have already expressed skepticism that wrongful harms must always be rights violations. Now I will argue that what qualifies as a legitimate exercise of rights requires democratic deliberation.

In colonial Massachusetts, the legitimate exercise of property rights did not include the unlimited right to exclude hunters from your land. There was a conflict between the right of the property owner to control access and the right of the people to harvest a public resource. On this conception of property rights, hunters had some access to private land. That is not the conception of property in all times and places. Different jurisdictions define property rights differently. ${ }^{8}$ The right of the property owner to exclude others from the land is not the same in all countries, nor is it the same across the United States. Different jurisdictions grant different rights of access. But if property rights are not proper objects of democratic deliberation, most of these jurisdictions are wrong about property rights. That is implausible because there seems to be more than one correct answer to this conflict. ${ }^{9}$

A libertarian can object that limiting the property owner's right of exclusion is always wrong. Property rights entail absolute rights of exclusion---there is only one right answer, and it is that no form of exclusion is prohibited. This again seems implausible. I cannot cross your property to save a life? To stop a fire that threatens my property? To escape a natural disaster that threatens my life? To access the only local water resource? The intuitions behind those forms of access are as strong as any intuition behind property rights. Still, suppose that there is only one correct answer with respect to access, and that property rights allow for exclusion in any and all cases.

Even if the libertarian is view is correct and property rights include an absolute right of exclusion, this does not settle the question of the spatial extension of that right. How far does shoreline property extend? How far do air rights extend?

6 JOHN LOCKE, SECOND TREATISE ON CIVIL GOVERNMENT (ch. 5) (1689).

${ }^{7}$ White, supra note 1.

${ }^{8}$ I am grateful to Dan Brudney for discussion on this point.

${ }^{9}$ You can accept Locke's view and conclude that self-ownership is inviolable without concluding that all forms of ownership are inviolable. Indeed, all forms of ownership cannot be inviolable, and thus in a democratic state, democratic deliberation must define the borders of legitimate property rights. 
Long, Ryan. "Ethics, Rights, and White's Antitrust Skepticism." The Antitrust Bulletin 61, no. 2 (2016):

336-341. (open access, non-formatted version)

In the previous case the libertarian had a move to make. I think that move is wrong, but it is coherent. These questions provide no such move. These issues cannot be settled a priori, they cannot be settled by any straightforward empirical investigation, and must be determined politically. Thus the absolute prohibition on democratic deliberation over property rights must be rejected.

White then objects that antitrust law makes property rights variable and dynamic according to background conditions and the acts of others. ${ }^{10}$ Aside from his principle that democratic legislatures should not interfere with property rights, he thinks that the way antitrust law makes property rights dynamic and sensitive to the acts and holdings of other persons is illegitimate. He thinks owners may do as they wish with their property, and that what counts as a legitimate exercise of their property rights is defined independently of the holdings and acts of other parties. "Under the classical conception of property rights, [consumers] have no right to interfere with the terms by which firms choose to dispose of their property."11

But in the Lockean conception, certain forms of use, hoarding, or disposal invalidate one's property rights. Legitimate exercise does not include everything that a property owner may freely choose to do with her property. Property rights are dynamic and sensitive to the holdings and acts of other persons. Locke argued that property rights are always variable by the "enough and as good" condition. In the state of nature, a person may appropriate unowned resources by mixing them with their labor. But they must leave enough and as good for others. Since the definition of "enough and as good" varies according to the resources available and the holdings of other parties, Lockean property rights are dynamic from their origin.

Locke also thought that property rights varied by whether a market uses barter or currency. Without currency, hoarding that leads to spoilage is not part of his conception of the legitimate exercise of property rights. In a currency system one can hoard without spoilage, and that constraint is therefore lifted. So even within a classical conception of property rights, indeed one that has been hugely influential to libertarian thought, what counts as a legitimate exercise of property rights is dynamic and sensitive to external conditions. It is also worth noting that Locke reached this position because he thought that property (and, by extension, the market) has the purpose of increasing the fruitfulness of the world and thereby increasing human welfare. The purpose is not merely to maximize individual autonomy.

\section{CONCLUSION}

I raised several objections to White's anti-antitrust argument. I objected to the principle that the state can only legitimately constrain conduct that violates rights, to the idea that property rights must be insulated from democratic deliberation, and to the claim that the market has no purpose other than maximizing and coordinating individual autonomy. I also argued that the harms caused by trusts are different in kind from the other harms caused by firms. I sketched a case that persons might

10 White, supra note 1.

${ }^{11}$ White, supra note 1. 
Long, Ryan. "Ethics, Rights, and White's Antitrust Skepticism." The Antitrust Bulletin 61, no. 2 (2016): 336-341. (open access, non-formatted version)

have a right to a competitive market, and that therefore trusts do violate rights. The main thread running throughout the entire critical discussion is that what counts as a legitimate exercise of property rights is dynamic, sensitive to various external conditions, and is the proper object of democratic deliberation. 